\title{
Game based Learning and using Course Learning, Collaboration and Management Tools in Black Board
}

\author{
Salma Mahgoub Gafer Elhag \\ Information Systems Department, \\ King Abdulaziz University \\ , Jeddah Saudi Arabia
}

\begin{abstract}
Teaching theoretical courses for undergraduate students requires to use more interactive tools to encourage student's participation. Interactive environment motivate students and fill the class with a positive learning spirit. This paper focuses on using game based learning to teach the concepts of EBusiness Strategies and Using Course Learning, Collaboration and Management Tools to in Black Board to support student participation and final evaluation of the proposed learning methodology. It was done at Information System Department at King Abdul-Aziz University
\end{abstract}

\section{General Terms}

Distance-learning, Game-based learning, Collaboration

\section{Keywords}

E-learning, Game-based learning, Black-Board

\section{INTRODUCTION}

Distance education emerged in response to the need of providing access to those who would otherwise not be able to participate in face-to-face courses(Beldarrain 2006).Egovernment, E-commerce and E-learning are all are all emerged with the use of ICT and the internet. A virtual experience could be considered in the e-environment when a student can learn by trial and error and building ex-perience. Similar to small children where the learning process of trial and error is part of real life; hence emerged the idea to use the new trend, game based learning paradigm as an aid in teaching theoretical concepts of our CPIS486 E-Business Strategies in the Faulty of Information and Technology at King Abdulaziz University.

This Paper examines the use of Virtonomics Busi-ness Virtual Simulation Game in teaching and use Black Board Course Collaboration and evaluation tools in assessing the process.

The rest of the page is organized as follows:

Section two Introduces pre-elementaries, while section three present the analysis Case study .Section four discuss and analyze student feedback. Finally section five and six are conclusion and references..

\section{PREELEMENTARIES}

\subsection{GAME BASED LEARNING}

People like playing games; they are fun and engaging. In fact, a recent survey showed that 55 percent of people would be interested in working for a company that offered games as a way to increase productivity. So maybe your vision of gamification is rewards, badges, and points for doing everyday stuff at work or even for brushing your teeth. But that's a narrow way of looking at gamification; a broader, more encompassing and more helpful way of looking at gamification exists
Studying only computer-based business games used to teach strategic management, Wolfe reviewed seven studies conducted between 1966 and 1988 .(Kapp 2012). The study was published in 1997. The studies all used at least one treatment and one control group. The control groups all used the instructional approach of case-based learning. The studies had the criteria of (1) comparing game use with at least one other instructional approach, (2) having predefined, objectively measured instructional objectives, and (3) having objectively measured learning outcomes.

The study concluded the following

Every study examined indicated that the game-based approach produced significant knowledge-level increases over the conventional case-based teaching method.

Deconstruct the fun in any good game, and it becomes clear that what makes it enjoyable is the built-in learning process.

To progress in a game is to learn; when we are actively engaged with a game, our minds are experiencing the pleasure of grappling with (and coming to understand) a new system. This is true whether the game is considered "entertainment" (e.g., World of Warcraft) or "serious" (e.g., an FAA-approved flight simulator).

The implications of delivering game experiences for education and training are enormous. In the US, nearly 170 million people played computer and videogames in 2008 , spending a record $\$ 11.7$ billion. Harness the power of welldesigned games to achieve specific learning goals, and the result is a workforce of highly motivated learners who avidly engage with and practice applying problem-solving skills (Pivec and Dziabenko 2004).

Because of good game design, more than 11 million subscribers spend an average of 23 hours per week immersed in World of Warcraft. A growing core of game-based learning experts use the same design principles to make it compelling for surgical students to practice and hone proper laparoscopic techniques on a virtual patient, or inspire first responders to frequently rehearse and sharpen their training in a simulated hazardous materials emergency. The emerging truth: the same factors that make well-designed games highly motivating also make them ideal learning environments. (http://www.newmedia.org/game-based-learning--what-it-iswhy-it-works-and-where-its-going.html, n.d.)

\subsection{Cpllaborative Learning And E-Teams In Black Board}

Blackboard Learn (previously the Blackboard Learning Management System), is a virtual learning environment and course management system developed byBlackboard Inc. It is Web-based server software which features course management, customizable open architecture, 
and scalable design that allows integration with student information systems and authentication protocols. It may be installed on local servers or hosted by Blackboard ASP Solutions. Its main purposes are to add online elements to courses traditionally delivered face-to-face and to develop completely online courses with few or no face-to-face meetings (Black Board. (n.d.). In Wikipedia. Retrieved April 16, 2016, from https://en.wikipedia.org/wiki/Blackboard_Learn).Follows a discussion of some collaboration learning tools available in blackboard:

\subsubsection{Groups}

Instructors can create groups of students and provide them with their own tools

\subsubsection{Wikis}

A Wiki, ideal for group projects, is a collaborative tool for students working together in creating and editing a Web document.

\subsubsection{Blog}

Can be individual or course wide and not accessible outside course

\subsubsection{Discussion Board}

May be used for many types of learning activities

\section{CASE STUDY ANALYSIS}

\subsubsection{Game selection}

We made an intensive search to select the best game that can be suitable to use it as testing game to be base for the game based learning proposal for our E-Business Course, Virtonomics game was selected.

\subsubsection{Virtonomics}

Virtonomics is a cool online strategy game. A player can start his own business and gain management, marketing and other skills. Play online and get the insights on running your own company in an outstanding business simulation browser game is an obvious challenging part of Virtonomics. And the best part of it is that it's completely free.

Virtonomics is a business-strategy oriented on-line game played as an MMOG (massive multiplayer online game) where the basics of management are tested. It is designed for fans of economic and strategic games, and to study the basics of management. The game itself requires an understanding of laws of real life economy, business and finance, yet players do not need a deeper understanding of economics or any special background education to take part. The game is helpful in meeting interesting people with common interests and making useful connections (Bla and Arh;Bold 2006).

\subsubsection{Introductory Seminar}

An introductory Seminar was given to the students in order to familiarize them with the game and determine and give them an idea about team formation. Here we created Black Board teams , and determine each student role in the team .The students were given guides, demos and videos to illustrate more about the game. Black Board Course Tools (Discussion Boards, Wikis and blogs) were created to enhance brainstorming and team collaboration.

\subsubsection{Game Scenario and Starting the Game}

To play; time of the game can fluctuate from one to several days according to the difficulty of the selected theme and the skills of the students. Figure 1 presents the basic steps of the game and it's time flow. The game starts with user (team leader) registration (Figure 2).

\begin{tabular}{|c|}
\hline - Team registration \\
\hline -Instructor Seminar \\
\hline •sharing subject \\
\hline - posting stand points \\
\hline $\begin{array}{l}\text { - posting the final team } \\
\text { achievements }\end{array}$ \\
\hline -Students feed back on the work \\
\hline - Final discion on on seminar \\
\hline
\end{tabular}

Figure 1. Time Plan Of the game

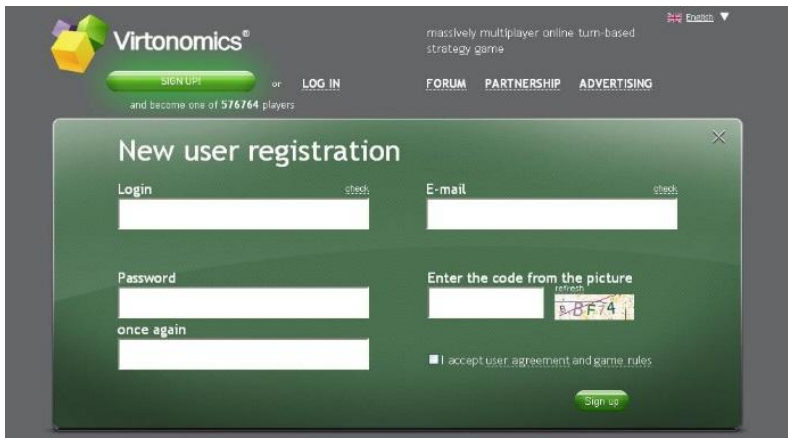

Figure 2. Virtonomics Registration.

Usually, each team has to choose a Strategy on the Game .Here we decided to choose a Retail Trade Company Simulation Game. Initially there will be a Cash and Assets and then the user can create a Store (Figure 3), which will deduct from his cash. The objective will be to make more revenues .He has to determine about

- New subdivision which will be managed through company representative offices) (Determine the country, city, specialization, size...etc.

- And the cost will be cut off from his/her account

- Create new enterprises

- Management

- $\quad$ Reporting

- Make money! (Purchase goods and hire sales assistants)

- $\quad$ Order goods (Figure 4 )

- Marketing and advertisement Strategy

Advertisement campaign can be set up (Figure 5). 


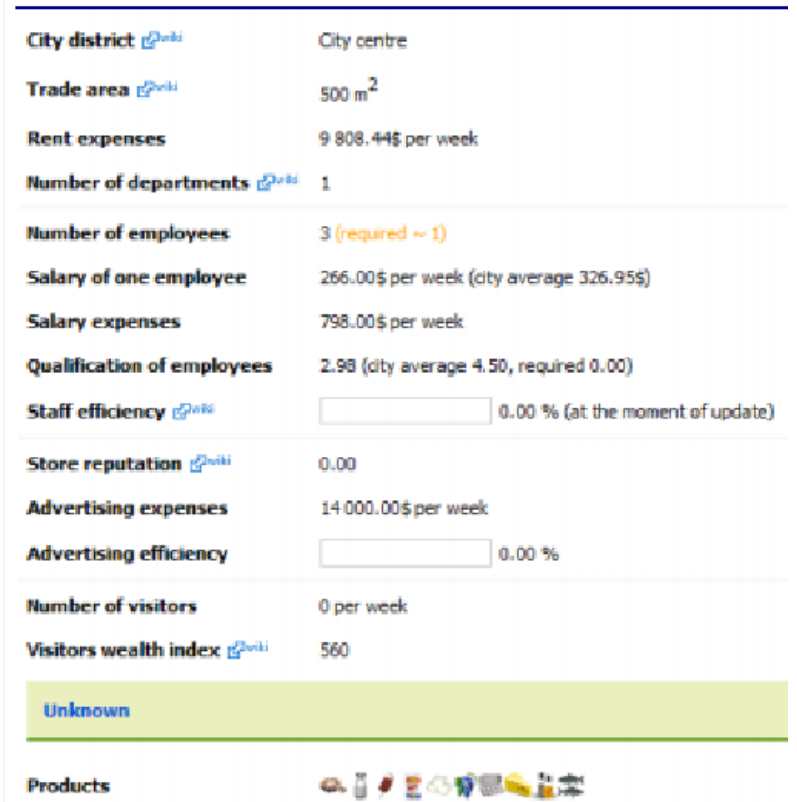

Figure 3.Setting a store

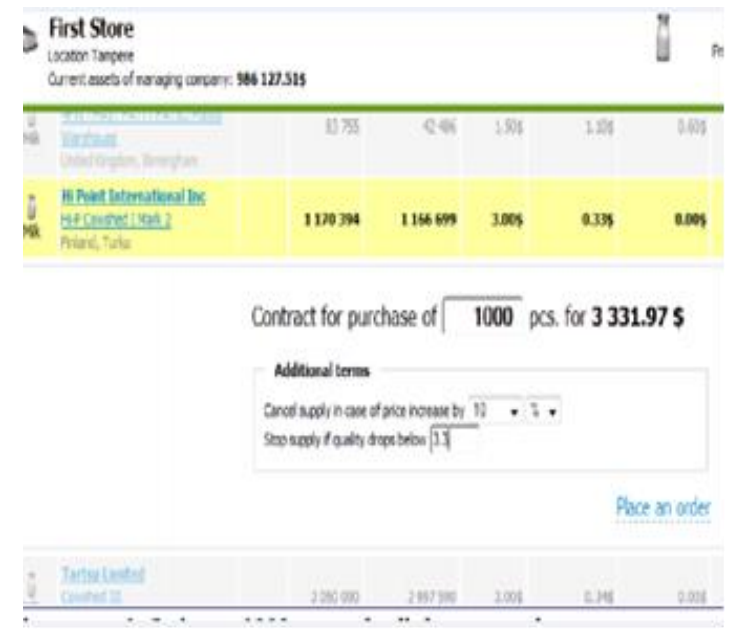

Figure 4. Ordering 1000 units of milk from a supplier

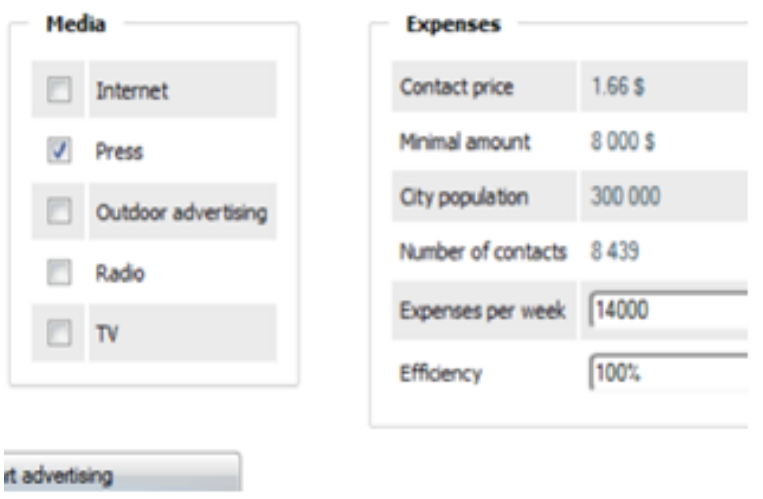

Figure 5. Setting up an advertisement Campaign

\section{ANALYSIS OF STUDENT FEEDBACK}

\subsubsection{Student Groups}

Total of 15 Students were distributed randomly into 3 groups. Then they used discussion boards and Wikis to choose a group moderator and to share ideas and brainstorm about different game strategies.

\subsubsection{Wikis}

Wiki for each group of student was created to ease the process of team collaboration about the project assignments and task

\subsubsection{Blogs}

Wiki for each group of student was created to ease the process to asses day to day and end of day progress in the game.

\subsubsection{Discussion Boards}

A Discussion Board were created for the Game based learning experience to share ideas about how to use different strategies at the game and how to earn money!

\subsubsection{Survey}

A Survey contains 6 simple questions was conducted to measure student satisfaction about the game based learning process and about how they felt using collaboration tools in black board Table 1 shows the results of the survey.

Table 1. Survey questions Results

\begin{tabular}{|c|l|c|c|}
\hline No & The Question & Yes & No \\
\hline 1 & $\begin{array}{l}\text { You Liked the idea of the Game } \\
\text { Based Learning! }\end{array}$ & $94 \%$ & 0.06 \\
\hline 2 & $\begin{array}{l}\text { You Prefer the more interactive } \\
\text { way in teaching and learning } \\
\text { theoretical courses }\end{array}$ & $\begin{array}{l}\text { Game based Learning in the } \\
\text { Learning environment }\end{array}$ & $0 \%$ \\
\hline 4 & $\begin{array}{l}\text { You would like to include the } \\
\text { It was exciting to play the game }\end{array}$ & $88 \%$ & $13 \%$ \\
\hline 5 & $\begin{array}{l}\text { I have benif from the Virtual } \\
\text { Concepts }\end{array}$ & $88 \%$ & $13 \%$ \\
\hline 6 & \begin{tabular}{l} 
It was easy to play the game \\
\hline
\end{tabular} & $75 \%$ & $25 \%$ \\
\hline
\end{tabular}

\section{CONCLUSION}

According to Student interaction using the Black Board Course collaboration tools, and Based on the Survey results we can see the majority of students prefer to engage the game based learning scheme and they find it more interactive and interesting way to learn the theoretical concepts of the Course. Most of them found the experience easy and interesting and benefited from it.

\section{ACKNOWLEDGMENTS}

Special thanks to King-Abdulaziz University, Faculty of Computing and Information Technology, Information Systems Department for its support to make this study. 


\section{REFERENCES}

[1] Beldarrain, Y. 2006. Distance education trends: Integrating new technologies to foster student interaction and collaboration. Distance education, 27, (2) 139-153

[2] Bla, A.J. \& Arh, T. Immersive Business Simulation Games: an Innovative Pedagogical Approach to eLearning and Education.

[3] Bold, M. 2006. Use of wikis in graduate course work. Journal of Interactive Learning Research, 17, (1) 5

[4] Godwin-Jones, R. 2003. Emerging technologies. Language Learning \& Technology, 7, (2) 12-16

[5] Johnson, H. 2007. Dialogue and the construction of knowledge in E-learning: Exploring studentsGiض perceptions of their learning while using BlackboardGiضls asynchronous discussion board. European Journal of Open, Distance and E-Learning, 10, (1)

[6] Kapp, K.M. 2012. The gamification of learning and instruction: game-based methods and strategies for training and education John Wiley \& Sons.

[7] Liaw, S.S. 2008. Investigating students perceived satisfaction, behavioral intention, and effectiveness of elearning: A case study of the Blackboard system. Computers \& Education, 51, (2) 864-873

[8] Mun, Y.Y. \& Hwang, Y. 2003. Predicting the use of web-based information systems: self-efficacy, enjoyment, learning goal orientation, and the technology acceptance model. International journal of humancomputer studies, 59, (4) 431-449

[9] Papastergiou, M. 2006. Course management systems as tools for the creation of online learning environments: Evaluation from a social constructivist perspective and implications for their design. International Journal on ELearning, 5, (4) 593

[10] Pivec, M. \& Dziabenko, O. 2004. Game-based learning framework for collaborative learning and student eteamwork. Internet: http://www.unigame.net/html/publications.html [May, 2008]

[11] Tragazikis, P., Kirginas, S., \& Gouscos, D. 2012. Digital games for entrepreneurial learning, innovation and creativity: examples and evaluation criteria. International Journal of Innovation and Regional Development 5, 4, (3-4) 314-337

[12] Trybus, J. (2009). Game-based learning: What it is, why it works, and where it's going. Availible from http://www.newmedia.org/game-based-learning--what-itis-why-itworks-and-where-its-going.html.Ref ID 16Reprint: Not in File

[13] Wikipedia: The free encyclopedia. (2014, January 21). FL: Wikimedia Foundation, Inc. Retrieved April 16, 2016, from http://www.wikipedia.org 